\title{
AKSES PEREMPUAN NELAYAN DALAM KEGIATAN PRODUKTIF (Studi Kasus di Desa Teluk, Kecamatan Labuan, Kabupaten Pandeglang, Banten)
}

\author{
*Istiana \\ Balai Besar Penelitian Sosial Ekonomi Kelautan dan Perikanan \\ Gedung Balitbang KP I Lt. 4 \\ Jalan Pasir Putih Nomor 1 Ancol Timur, Jakarta Utara \\ Telp: (021) 64711583 Fax: 64700924 \\ *e-mail: isti0112@yahoo.com \\ Diterima 3 Maret 2014- Disetujui 25 Mei 2014
}

\begin{abstract}
ABSTRAK
Penelitian ini bertujuan untuk menjelaskan akses perempuan nelayan dalam kegiatan produktif. Penelitian ini dilaksanakan pada tahun 2011 di Desa Teluk, Kecamatan Labuan, Kabupaten Pandeglang, Propinsi Banten. Subyek penelitian yaitu sebanyak 30 orang (diantaranya 15 perempuan nelayan). Penelitian ini merupakan penelitian kualitatif dengan menggunakan paradigma interpretatif. Pengumpulan data dengan cara observasi, wawancara bebas secara mendalam. Data terkumpul diklasifikasikan sesuai topik penelitian kemudian dianalisis dengan pendekatan analisis gender. Hasil penelitian menunjukkan bahwa kegiatan produktif perempuan nelayan di lokasi kasus adalah sebagai pengolah pemindangan ikan tongkol. Akses perempuan nelayan terhadap sumberdaya, modal dan pasar tergolong mudah, namun masih terkendala pada akses informasi untuk pengembangan usaha. Perempuan nelayan masih mengalami dampak negatif dari ketimpangan gender, karena laki-laki nelayan selalu mendapatkan peluang informasi lebih besar dibandingkan perempuan nelayan. Semestinya perempuan nelayan sebagai anggota masyarakat nelayan punya hak dan kewajiban yang sama dengan laki-laki nelayan. Peranan perempuan nelayan sebagai pelaku ekonomi tidak boleh diabaikan karena potensi dan partisipasinya dalam pembangunan memang signifikan. Untuk itu, dibutuhkan upaya pemberdayaan bagi perempuan nelayan terutama yang bertujuan meningkatkan kualitas (kompetensi) dan akses produktif perempuan nelayan, sehingga perempuan nelayan memiliki kemampuan untuk berkontribusi dan mengembangkan potensinya secara maksimal dalam pembangunan ekonomi desa pesisir.
\end{abstract}

Kata kunci: akses perempuan, kegiatan ekonomi, nelayan

\section{Abstract : Fishermen Women's Access on Productive Activities. by Istiana}

The purpose of research to describe fishermen women's access on productive activities (economic). This research was conducted in 2011 at the Teluk village, Labuan District, Pandeglang, Banten Province. The subject research as many as 30 people (including 15 women fishers). This research is a qualitative research using interpretative paradigm. Collecting data by observation, indepth interviews. Data are classified according research topics and then analize with gender analysis. The research results explained that the women productive activities at the village is as Tongkol (Euthynus sp.) ripe processing. Women's access to resources, capital and market classified easily. However, women's access hampered in information access for business development. So far, information about technology, mentoring and business support reserved only for fishermen (men). There appeared to be gender disparity, men (fishermen) always get a greater information opportunities than women. This happens on the supporting programs for the fishermen communities empowerment. While women are also part of the fishermen community have the same rights and responsibilities as men. The coastal village economy depends on fluctuations fisheries productivity and it will affect the economic power of coastal villages. The women role as economic actors should not be overlooked because of their potential and participation in development is significant..

Keywords : women's access, economic activity, fishers

\section{PENDAHULUAN}

Tidak diragukan lagi bahwa peran wanita nelayan dalam mensejahterakan rumah tangga adalah sangat besar. Terlebih mengenai keterlibatannya dalam kegiatan produktif untuk menyanggah ekonomi keluarga. Ketidakpastian pendapatan nelayan yang lebih disebabkan cuaca ekstrem perairan menjadikan nelayan tidak memperoleh pendapatan. Kondisi tersebut memaksa perempuan nelayan untuk lebih banyak berperan dalam membantu ekonomi keluarga. Umumnya perempuan nelayan melakukan kegiatan pasca penangkapan yaitu penjualan ikan, pengolahan, pengeringan ikan dan juga kegiatan disektor non perikanan.

Masyarakat nelayan merupakan masyarakat yang aktif dalam memanfatkan sumberdaya alam yang ada, salah satunya adalah masyarakat nelayan Pandeglang (Propinsi Banten). Menilik potensi sumberdaya perikanan laut yang dimiliki daerah ini terlihat masih sangat terbuka untuk dikembangkan. Pengembangan tersebut dapat dilakukan secara intensifikasi dan ekstensifikasi (pengembangan) produksi, mengingat 
Kabupaten Pandeglang memiliki panjang pantai 307 km yang membentang sepanjang pesisir Barat dan Selatan Kabupaten Pandeglang sampai perbatasan Kecamatan Malingping (Kabupaten Lebak). Selama ini intensifikasi dan ekstensifikasi sumberdaya perikanan laut ini dilakukan dengan cara pengembangan industri pengalengan, penjemuran/pengeringan ikan, optimalisasi fungsi Tempat Pelelangan Ikan (TPI), pembangunan tambak dan hatchery (BPS, 2012).

Melihat besarnya potensi diatas, tentu sangat menjanjikan kehidupan yang sejahtera bagi nelayan jika potensi perikanan laut dimanfaatkan secara optimal oleh masyarakat nelayan. Namun kenyataannya, nelayan selalu identik dengan kemiskinan. Kemiskinan yang selalu melekat pada masyarakat nelayan seperti yang diungkapkan (Kusnadi, 2002:26-27) dalam kehidupan nelayan terdapat kesenjangan sosial ekonomi yang tinggi dan adanya ketimpangan pendapatan yang mengakibatkan kemiskinan nelayan tidak mudah diatasi dan merupakan persoalan krusial yang dihadapi. Fauzi (2005:17) juga menjelaskan bahwa kemiskinan nelayan masih terjadi di tengah melimpahnya kekayaan sumber daya laut. Hampir sebagian besar nelayan Indonesia masih hidup dibawah garis kemiskinan dengan pendapatan kurang dari sepuluh dollar Amerika per bulan. Jika dilihat dari konteks Millenium Development Goals, pendapatan sebesar itu termasuk dalam extereme poverty, karena lebih kecil dari satu dollar Amerika per hari.

Kusnadi (2003) menjelaskan bahwa kemiskinan dan rendahnya derajat kesejahteraan sosial menimpa sebagian besar kategori nelayan tradisional/nelayan buruh, dimana nelayan merupakan kelompok yang menempati lapisan sosial paling miskin dibandingkan kelompok sosial lainnya. Masalah ini tidak hanya mengganggu proses pembangunan nasional di bidang perikanan dan kelautan, tetapi juga menimbulkan kerawanan sosial dan hambatan pengembangan sumber daya manusia berkualitas untuk menunjang keberhasilan pembangunan bangsa di masa depan. Disisi lain Kusnadi (2001) juga menjelaskan bahwa perempuan nelayan merupakan salah satu komponen yang sangat penting dalam pembangunan pesisir karena posisinya yang strategis dalam kegiatan berbasis perikanan dan kelautan sebagai pedagang pengecer, pengumpul ikan, pedagang besar, buruh upahan, maupun tenaga pengolah hasil perikanan. Namun kegiatan perikanan menggambarkan suatu keadaan bahwa perempuan belum mendapatkan keadilan dan kesetaraan gender. Salah satunya adalah beban pekerjaan ganda yang harus dilakukan perempuan. Inilah bentuk bias gender yang ada di masyarakat nelayan.

Memang dalam kehidupan bermasyarakat, setiap orang dapat memenuhi kebutuhannya melalui sektor riil. Pada sektor riil inilah, perempuan berpartisipasi mendukung perekonomian rakyat. Namun menurut Murniati (2004:169) bahwa tradisi telah memberi tugas kepada perempuan untuk menyelesaikan pekerjaan domestik, pekerjaan rumah tangga dan memelihara kehidupan keluarga. Perempuan yang menjadi istri dan ibu, diberi tugas atas dasar gender untuk memelihara anak dan suami serta menjaga kesehatan mereka. Sedangkan pekerjaan publik untuk menentukan kehidupan bermasyarakat serta mencari penghasilan keluarga, diserahkan kepada laki-laki. Walaupun keadaan zaman mendorong perempuan di sektor publik, tetapi pandangan yang bias gender tidak berubah. Akibatnya pandangan yang bias gender ini menimbulkan berbagai ketidakadilan, termasuk ketidakadilan gender dalam aspek ekonomi.

Gambaran bias gender itulah yang ada dalam masyarakat Indonesia yang lebih banyak beridiologi patriarkhis. Mencermati berbagai fenomena kehidupan nelayan yang sangat komplek dengan permasalahan pembangunan yaitu sering dikaitkannya nelayan sebagai 'penghambat' pembangunan karena 'kemiskinannya'. Padahal besar perjuangan yang dilakukan nelayan baik laki-laki maupun perempuan untuk mendapatkan kesejahteraan hidup. Satu kajian yang menarik untuk didiskripsikan yaitu mengenai akses perempuan nelayan dalam kegiatan produktif (ekonomi).

\section{METODE PENELITIAN}

\section{Waktu dan Lokasi Penelitian}

Penelitian ini dilaksanakan pada tahun 2011 di lokasi kasus Desa Teluk, Kecamatan Labuan, Kabupaten Pandeglang, Propinsi Banten. Alasan pemilihan lokasi kasus tersebut adalah karena mayoritas istri nelayan melakukan pengolahan hasil perikanan berupa pemindangan.

\section{Responden Penelitian}

Subyek penelitian yaitu sebanyak 30 orang antara lain sebanyak 15 wanita nelayan menjadi informan kunci dan 10 orang menjadi informan tambahan yaitu 1 orang Dinas Kelautan dan Perikanan, 1 orang perangkat desa dan 8 nelayan.

\section{Jenis dan Sumber Data}

Data yang digunakan dalam penelitian ini adalah data primer yang diperoleh dengan cara observasi, wawancara bebas secara mendalam. Di samping itu, untuk mendukung penelitian ini digunakan data sekunder yang terkait dengan penelitian.

\section{Metode Analisis}

Penelitian ini merupakan penelitian kualitatif dengan menggunakan paradigma interpretatif. Penggunaan paradigma ini bertujuan untuk mendiskripsikan akses perempuan nelayan dalam 
kegiatan produktif karena paradigma interpretatif ini menggunakan pendekatan subyektivitas dalam analisa sosialnya. Penggunaan paradigma interpretatif dalam penelitian ini karena ingin memahami kenyataan sosial menurut apa adanya, mencari sifat yang paling dasar dari kenyataan sosial menurut pandangan subyektif dan kesadaran seseorang yang langsung terlibat dalam peristiwa sosial bukan menurut orang lain yang mengamati (Salim, 2006). Selanjutnya, data yang terkumpul dipahami secara emik, etik dan di analisis dengan analisis gender.

\section{HASIL DAN PEMBAHASAN}

\section{Profil Kegiatan Perikanan}

Kecamatan Labuan memiliki luas $15,65 \mathrm{~km}^{2}$ yang terdiri dari 9 desa, 71 rukun warga (RW) dan 216 rukun tetangga (RT). Salah satu desa kecil diantaranya adalah desa Teluk yang memiliki luas $1,97 \mathrm{~km}^{2}$ atau sekitar $12,59 \%$ dari luasan kecamatan. Mayoritas nelayan yang menetap di desa ini merupakan penduduk lokal (asli). Selain penduduk lokal, juga terdapat nelayan pendatang yang umumnya berasal dari daerah Jawa Tengah, Surabaya, Dadap dan Tegal. Bentuk kegiatan usaha penangkapan ikan di desa ini dikategorikan sebagai usaha perikanan yang berskala kecil. Kegiatan penangkapan dapat dilakukan sepanjang tahun dan sangat bergantung dari musim. Hal ini akan berdampak pada penentuan daerah penangkapan (fishing ground) yang menjadi sasaran penangkapan.

Daerah penangkapan ikan di Kecamatan Labuan adalah Selat Sunda, Selatan Jawa/Samudera hindia dan Laut Jawa. Berdasarkan wawancara dengan nelayan daerah penangkapan yaitu sekitar Selat Sunda, Tanjung Panaitan, Kepulauan seribu, Kerakatau, Rompang, Sumur, Kelapa Koneng, Pulau Pucang, Kalianda, Cemara, Karang bawah dan Batu Item. Daerah penangkapan ini ditempuh para nelayan sekitar $3-4$ jam perjalanan. Penentuan daerah penangkapan ikan yang dilakukan oleh nelayan-nelayan di desa ini umumnya masih berpedoman pada faktor-faktor alam.

Nelayan masih menggunakan pengetahuan sederhana seperti adanya burung yang terbang di atas perairan atau riak di air yang menandakan adanya ikan. Dengan hanya mengandalkan sebatas pengetahuan tradisional ini maka nelayan yang beroperasi menangkap ikan berada pada keadaan berburu atau pergi dengan tujuan mencari yang tidak pasti letaknya. Akan tetapi karena tingkah laku ikan yang sudah diketahui nelayan yaitu dimana ikan memijah dan dimana ikan biasa berkelompok mencari makan maka hal ini dapat digunakan nelayan dalam menentukan posisi ikan. Keberadaan kelompok ikan juga juga dapat diketahui dengan melihat permukaan laut yang berbuih, adanya ikan-ikan yang melompat-melompat di permukaan atau burung yang menukik dan menyambar ke permukaan laut. Selain itu, penentuan daerah penangkapan juga ditentukan berdasarkan pengalaman dan informasi dari kapal yang baru mendarat.

Intensitas penangkapan ikan oleh nelayan sengat dipengaruhi oleh keadaan musim angin. Terdapat tiga musim penangkapan yaitu 1) puncak musim atau musim timur, pada musim ini aktivitas penangkapan mencapai frekuensi tertinggi sehingga menyebabkan terjadinya musim puncak pendaratan ikan yang biasanya terjadi sekitar bulan Mei sampai Agustus. Nelayan menyebutnya dengan rejeh (musim ketika perolehan ikan banyak), 2) musim normal atau musim peralihan, pada musim ini aktivitas penangkapan yang dilakukan nelayan berada pada frekuensi normal dan menghasilkan volume produksi ikan normal terjadi dua kali dalam setahun, yaitu musim peralihan awal yang terjadi sekitar bulan Maret sampai April dan musim peralihan akhir yang terjadi sekitar bulan September sampai Oktober, 3) musim paceklik atau musim barat, pada musim ini cuaca dalam kondisi yang buruk sehingga nelayan jarang atau bahkan sama sekali tidak pergi melaut dengan alasan keamanan dan keselamatan sehingga hal ini mengakibatkan frekuensi pendaratan ikan rendah. Umumnya terjadi sekitar bulan November sampai Februari. Nelayan menyebutnya musim paila ( musim ketika perolehan ikan sedikit ).

Gambaran kegiatan perikanan diatas juga sesuai dengan gambaran kegiatan masyarakat nelayan yang disampaikan Kusandi (2002:86) secara lebih rinci, ciri-ciri usaha nelayan tradisional: (1) teknologi penangkapan bersifat sederhana dengan ukuran perahu yang kecil, daya jelajah terbatas, daya muat perahu sedikit, daya jangkau alat tangkap terbatas, dan perahu dilajukan dengan layar, dayung, atau mesin PK kecil; (2) besaran modal usaha terbatas; (3) jumlah anggota organisasi penangkapan kecil antara 2-3 orang, dengan pembagian peran bersifat kolektif (non -spesifik), dan umumnya berbasis kerabat, tetangga dekat, dan atau teman dekat; (4) orientasi ekonomisnya terutama diarahkan untuk memenuhi kebutuhan dasar sehari-hari.

\section{Peran Perempuan Pada Kegiatan Produktif}

Dari hasil observasi penelitian menunjukkan bahwa kegiatan produktif perempuan nelayan desa Teluk adalah kegiatan pengolahan hasil perikanan antara lain mayoritas pemindangan dan pengeringan atau penggaraman. Bahan produksi pengolahan yaitu ikan tongkol merupakan hasil tangkapan wilayah pesisir Labuan. Peran perempuan dalam kegiatan produktif ini sangat fungsional. Hal ini terlihat dari kemandiriannya dalam usahanya mulai dari memproduksi, memasarkan hingga manajemen usaha. Perempuan ini juga mempunyai wewenang atas usahanya (keputusan) karena dia juga berperan sebagai pemilik usaha. Hasil dari usaha tersebut dirasakan sangat membantu perekonomian keluarga. 
Teknologi yang digunakan masih bersifat tradisional. Hal ini dibuktikan dengan penggunaan alat produksi yang banyak diperoleh dipasar tradisional seperti panci/langseng ukuran 36, bak plastik atau keranjang bambu untuk mencuci ikan dan tungku pemasak berbahan bakar kayu. Bahan baku tambahan yang digunakan pun mudah diperoleh seperti daun pisang, garam dan kunyit yang ketersediaannya selalu ada. Berbeda dengan bahan baku utama yaitu ikan tongkol, yang terkadang tidak dapat terpenuhi karena tergantung dari hasil laut. Pengaruh musim yang ada berdampak pada jumlah hasil tangkapan dan harga ikan. Umumnya perempuan nelayan ini mendapatkan bahan baku ikan tongkol dari pedagang ikan yang menyuplai setiap hari. Dalam satu dusun, yang menyuplai ikan tongkol adalah satu pedagang ikan.

Kegiatan usaha dilakukan dirumah masing-masing dengan memanfaatkan dapur rumah tangga dan atau pekarangan belakang rumah sebagai tempat produksi. Proses pemindangan ikan tongkol dilakukan pada sore hari. Ikan tongkol terlebih dahulu dicuci (umumnya menggunakan air sumur) kemudian diberi bumbu (kunyit dan garam) lalu disusun rapi dalam langseng dan dimasak selama 3 hingga 4 jam. Setelah dimasak, ikan diangkat dan diangin-anginkan diatas lantai dapur atau dipekarangan belakang rumah. Kegiatan produksi ini dilakukan berbarengan dengan tugas perempuan nelayan sebagai istri dan ibu yang memberikan pelayanan pada anggota keluarga. Hal ini bisa dilakukan karena proses pemasakan pindang tidak perlu perlakuan khusus sehingga bisa ditinggal atau dimanfaatkan dengan mengerjakan pekerjaan lain.

Kemasan produk pun terlihat sederhana karena ikan pindang yang dijual hanya dibungkus kertas koran atau daun pisang. Area pemasaran produk terbatas hanya daerah lokal atau hanya lingkup kecamatan Labuan. Perempuan nelayan juga menjadi product sales dengan menjual sendiri ikan pindang ke pasar lokal desa dengan rentang waktu jam 6 pagi hingga jam 1 siang. Jika ikan pindang tidak habis dijual, maka dilakukan proses produksi ulang yaitu memasak pindang kembali pada langseng kemudian diangin-anginkan. Kemudian pindang tersebut dijual bersamaan dengan pindang baru. Menurut informan, konsumen jarang dapat membedakan jenis pindang baru ataupun yang dipanaskan kembali karena informan selalu menjaga tekstur pindang dengan baik pada saat pemasaran.

Dari penjelasan diatas menunjukkan peran perempuan dalam ekonomi keluarga sangat besar. Hal ini terbukti dari banyaknya curahan waktu yang diberikan yaitu sekitar 10-12 jam per hari. Waktu tersebut merupakan akumulasi dari waktu produksi dan pemasaran produk. Disisi lain, peran perempuan wajib dijalankan pada rumah tangga atas statusnya sebagai istri dan ibu dalam pekerjaan domestik. Dan perempuan juga tetap menjalankan kegiatan sosialnya sebagai anggota masyarakat seperti pengajian, arisan dan PKK.

\section{Akses Perempuan Nelayan}

Tidak dapat dipungkiri bahwa perempuan nelayan berperan penting dalam meningkatkan ekonomi keluarga. Sudah terbukti perempuan nelayan mempunyai potensi yang handal untuk berbisnis, terutama bisnis yang berkaitan dengan produk perikanan seperti bakul, pengolah ikan dan kegiatan lain yang sifat kegiatannya bisa dilakukan sehari-hari tanpa mengabaikan pekerjaan domestiknya. Sebenarnya bisnis mereka telah lama dilakukan namun jarang dipublikasikan karena sifat usahanya yang dianggap sebagai sampingan. Bisnis tersebut juga sangat menentukan berjalan atau tidaknya arus hasil perikanan dari produsen ke konsumen.

Hasil penelitian menunjukkan bahwa pengembangan produk olahan skala mikro yang dihasilkan wanita nelayan menemui beberapa keterbatasan seperti kualitas produk rendah, belum sesuai standar kualitas dan keamanan pangan, kurangnya pengetahuan dan ketrampilan dalam pengolahan dan manajemen usaha, kurangnya informasi teknis dan pasar, kurangnya modal, peralatan dan sumberdaya lainnya, serta kemampuan volume produksi terbatas. Hal ini terkait dengan keterbatasan akses perempuan terhadap pengembangan kegiatan produktif. Akses perempuan merupakan suatu hal penting untuk peningkatan pendapatan hasil usaha dan ekonomi keluarga.

Selama ini akses perempuan untuk mendapatkan modal tetap berupa peralatan usaha perempuan nelayan menggunakan jasa pinjaman dari pedagang di sekitar rumahnya yang pembayaran secara angsuran setiap hari (kredit). Uang angsuran yang digunakan merupakan uang yang diperuntukkan konsumsi keluarga. Sedangkan modal untuk biaya variabel bahan baku ikan tongkol diperoleh dari pedagang ikan langganannya. Biasanya, perempuan nelayan membayar modal tersebut setelah ikan pindang dipasarkan. Transaksi suplai ikan tongkol dilakukan pada sore hari begitu juga pembayaran suplai tongkol pada hari sebelumnya. Modal biaya variabel lainnya juga menggunakan uang konsumsi keluarga.

Dalam pengolahan usaha, perempuan nelayan melakukan aktivitas usahanya secara mandiri tanpa ada campur tangan tenaga kerja keluarga lainnya. Begitupun juga dalam memasarkan produk, perempuan nelayan melakukan sendiri pengelolaan pemasarannya mulai dari pengemasan, pengangkutan ke pasar dan menjadi pemasarnya (product sales). Kemasan pindang memang sederhana yaitu dibungkus kertas koran atau daun pisang. Akses jalan dan transportasi menuju pasarpun juga mudah (jalan kaki atau naik ojeg). Perempuan nelayan juga menentukan sendiri harga produk yang disesuaikan dengan harga pasar di desa.

Gambaran perputaran modal tersebut menjelaskan bahwa akses perempuan nelayan terhadap modal dapat dikategorikan mudah walaupun menggunakan lembaga pemodalan non formal yaitu 
pedagang ikan yang sekaligus memberikan pinjaman modal bahan baku ikan tongkol dan 'tukang kredit' peralatan rumahtangga. Akses pemodalan usaha perempuan nelayan memang belum bisa menembus lembaga pemodalan formal walaupun terdapat lembaga pemodalan formal yaitu BPR dan Bank konvensional lainnya. Selama ini perempuan nelayan belum pernah berhubungan dengan Bank formal dengan alasan tidak mau dirumitkan dengan birokrasi dan adanya ketakutan agunan akan hilang jika tidak bisa membayar. Padahal selama ini mereka belum pernah mencoba berhubungan dengan bank konvensional, yang didengar hanya cerita dari pedagang pasar pada saat memasarkan pindang.

Mengenai akses perempuan nelayan terhadap sumberdaya, terlihat akses tersebut tidak secara langsung (melalui tangan kedua) tetapi akses tersebut dapat dikategorikan mudah karena suplainya selalu ada. Suami mereka pun terkadang juga mendapatkan ikan tongkol namun hasil tangkapannya tidak diberikan pada istri sebagai bahan baku olahan, selalu dijual pada pengepul dengan alasan 'kebiasaan'. Disisi lain perempuan nelayan pun juga tidak mengharapkan hasil tangkapan suaminya untuk jadi bahan baku pindang karena ketersediaannya tidak setiap hari. Jika mereka memutuskan hubungan dengan pedagang langganannya, maka juga akan memutus usaha pindangnya karena pedagang tidak akan melayaninya selama 7 hari sebagai sanksinya. Daripada usaha pemindangan terputus, perempuan tetap melakukan transaski dengan pedagang langgangannya.

Begitupun juga aksesnya pada pemasaran produk dapat dikategorikan mudah karena masingmasing sudah memiliki jaringan pasar tersendiri. Strategi pemasaranpun masih sederhana yaitu melalui pelanggan tetapnya yang menginformasikan produknya ke konsumen lain tanpa ada imbalan apapun. Terlihat dalam memanajemen usaha belum rapi seperti keuangan yang belum terpisah dengan keuangan konsumsi keluarga dan proses produksi yang berlangsung di dapur rumah tangga. Hal ini terkait dengan pendidikan informan yang hanya lulusan Sekolah Dasar dan mereka juga tidak memiliki kemampuan ketrampilan mengolah usaha untuk lebih baik.

Selain itu akses perempuan nelayan untuk mendapatkan informasi dapat dikategorikan sulit karena untuk mendapatkan informasi mengenai teknologi usaha, trainning diversifikasi usaha, bantuan dan pendampingan usaha sulit didapatkan. Sebenarnya mereka menginginkan usahanya lebih berkembang, mereka ingin menggunakan teknologi tepat guna yang bisa memproduksi hasil secara cepat dan banyak dengan rasa serta tekstur ikan pindang yang sama dalam waktu singkat agar bias memenuhi permintaan konsumen/ pelanggan. Menurut mereka, informasi-informasi tersebut sangat terbatas dan kebanyakan informasi pengembangan usaha hanya untuk usaha penangkapan ikan bukan untuk pengolahan. Selama ini programprogram bebantuan hanya diperuntukkan nelayan saja antara lain Pemberdayaan Ekonomi Masyarakat Pesisir tahun 2007 dan program Nasional Pemberdayaan Masyarakat (PNPM) tahun 2010.

Disinilah terlihat ketimpangan gender, gender didefinisikan sebagai perbedaan-perbedaan sifat, peranan, fungsi dan status antara laki-laki dan perempuan bukan berdasarkan pada perbedaan biologis, tetapi berdasarkan relasi sosial budaya yang dipengaruhi oleh struktur masyarakat yang lebih luas. Laki-laki (nelayan) selalu mendapatkan peluang informasi lebih besar ketimbang perempuan seperti terlihat pada program bebantuan untuk masyarakat nelayan. Padahal perempuan juga menjadi anggota masyarakat nelayan yang punya hak dan kewajiban yang sama dengan lakilaki. Masyarakat desa ini masih memegang kuat nilainilai patriarki tetapi tidak mengikat perempuan untuk aktif dalam kegiatan produktif. Artinya mereka wajib menjalankan tugasnya sebagai ibu rumah tangga dan juga membantu mencari tambahan ekonomi keluarga.

\section{Ketimpangan Gender pada Akses Produktif Perempuan Nelayan}

Segi ekonomi peran perempuan dalam memperkuat penyangga ekonomi keluarga terbukti fungsional, dan bahkan sangat strategis. Di tengah keterbatasan pendidikan, ketrampilan dan kungkungan nilai-nilai patriarkhi yang bias gender, kesempatan dan peluang bagi perempuan untuk terlibat di kegiatan produktif sangat luas. Namun akibat keterbatasan akses informasi menyebabkan pemindangan dilakukan dirumah masing-masing. Ini membuat standar mutu pindang yang tidak seragam di satu desa. Kemasan produk juga seadanya, hal ini juga yang menjadikan pemasaran pindang hanya terbatas pada pasar lokal saja. Sektor kenelayanan seharusnya memberi peluang besar bagi bangkitnya sumber mata pencaharian lain yang masih berkaitan dengan pengolahan hasil panen ikan, seperti industri pindang, pembuatan ikan asap, kerupuk, serta pengeringan dan perdagangan ikan. Wilayah mata pencaharian tersebut menyerap tenaga kerja, sebagian besar adalah perempuan nelayan.

Upaya mengangkat perekonomian keluarga nelayan bukan perkara mudah. Kemiskinan yang mendera keluarga nelayan cenderung menempatkan perempuan dalam posisi marjinal. Mereka tak percaya diri dan kurang gigih menjalankan usaha karena tidak ada pendampingan dan informasi yang cukup. Membantu, melindungi dan memperdayakan perempuan pesisir agar tidak mengalami proses marginalisasi akibat pemberdayaan masyarakat lebih banyak diperuntukkan pada laki-laki. Pemberdayaan yang bertujuan untuk meningkatkan kualitas manusia di wilayah pesisir seharusnya memperhatikan kondisi perempuan maupun laki-laki atau bersifat sensitif gender. Tidak hanya membutuhkan pemahaman bahwa mereka adalah bagian dari penduduk lokal rentan marginalisasi tetapi juga harus dipahami posisi mereka sebagai perempuan 
yang acapkali masih terbelenggu oleh nilai budaya yang sifatnya patriarkhis. Peran produktif perempuan nelayan hanya dapat dioptimalkan apabila faktor penghambat yang melingkupinya teridentifikasi dengan baik.

Ketimpangan gender terutama pada akses produktif yang ada di masyarakat membuat perempuan nelayan sukar meningkatkan kemampuan mereka untuk berkontribusi dan mengembangkan potensinya secara maksimal. Akses terhadap informasi, pemanfaatan sumber daya alam, pendidikan, fasilitas kredit, dan hak untuk mengemukakan pendapat merupakan unsur-unsur yang perlu diperjuangkan guna keluar dari ketimpangan gender karena situasi yang berbeda antara perempuan dan laki-laki. Kajian tentang peran perempuan dalam nafkah rumah tangga, utamanya di pedesaan seperti yang dilakukan oleh Azahari (2008), menunjukkan bahwa peranan perempuan dalam sistem nafkah rumah tangga cukup signifikan. Kondisi ini menunjukkan bahwa peranan perempuan sebagai pelaku ekonomi tidak boleh diabaikan, bahkan diperlukan dukungan teknologi untuk menunjang peranan perempuan dalam kegiatan sosial dan ekonomi agar para perempuan dapat mengalokasikan waktunya lebih banyak pada kegiatan produktif tanpa meninggalkan peranannya pada kegiatan domestik.

Pengolahan sumber daya perikanan merupakan potensi utama untuk menggerakkan perekonomian desa-desa pesisir. Oleh karenanya, perekonomian desa pesisir fluktuatif karena sangat bergantung pada tinggi rendahnya produktivitas perikanan. Jika produktivitasnya tinggi, tingkat penghasilan nelayan akan meningkat. Situasi demikian memengaruhi kuat-lemahnya perekonomian desa pesisir. Untuk memberdayakan dan meningkatkan peran perempuan, terutama di daerah ekplorasi yang dibutuhkan sebetulnya bukan sekedar kebijakan dan keberpihakan pemerintah terhadap nasib usaha mikro yang diketuni perempuan tetapi juga harus dibarengi upaya-upaya yang menghapuskan berbagai bentuk ketimpangan gender yang selama ini masih dialami perempuan. Dampak ketidaksetaraan gender akan mempengaruhi kehidupan seseorang melalui pertumbuhan ekonomi. Keterbatasan akses terhadap informasi, tanah, sumberdaya akan mengurangi kemampuan perempuan dan laki-laki mencari penghasilan (Anonymous, 2005).

Seluruh warga negara indonesia, tanpa kecuali, mempunyai tugas dan kewajiban berpartisipasi dalam pembangunan negara dan bangsa. Sebagai timbal baliknya, seluruh warga negara mempunyai hak untuk menikmati hasil pembangunan. Semua kegiatan pembangunan diarahkan pada tujuan pembangunan yang mencita-citakan masyarakat yang adil dan makmur. Kata adil disebut lebih dulu karena memang pemerataan yang harus lebih didahulukan. Cita-cita bangsa ini harus diperjuangkan oleh semua warga negara yang setia pada bangsanya. Perempuan, termasuk warga negara yang mempunyai tugas, kewajiban dan hak yang sama pula. Namun lain dengan kenyataannya, situasi ini masih membutuhkan perjuangan, khususnya oleh kaum perempuan sendiri. Dari sudut kuantitatif, jumlah perempuan Indonesia lebih dari separuh jumlah seluruh penduduk. Angka tersebut menjadi penting, dikaitkan dengan potensi sumberdaya manusia untuk mendukung pembangunan. Kenyataannya, potensi perempuan dan partisipasinya dalam pembangunan memang luar biasa. (Murniati, 2004: 49-50).

Ketimpangan atau ketidaksetaraan gender merapuhkan pembangunan, maka upaya perbaikan kesetaraan gender harus menjadi bagian dari strategi pembangunan berkelanjutan. Ketidaksetaraan dalam hak, sumberdaya maupun politik tidak saja merugikan perempuan secara umum tetapi juga merugikan anggota masyarakat lain sekaligus menghambat pembangunan. Menurut (Anonymous, 2005) ketidaksetaraan gender terutama sangat merugikan masyarakat di negara berpendapatan rendah dan secara umum kaum miskinlah penanggung beban terberat dari ketidaksetaraan gender. Dampak terburuk dari ketidaksetaraan gender adalah merosotnya kehidupan dan kualitas kehidupan manusia. Akhirnya, Ketidaksetaraan gender memperlemah kualitas tata laksana kepemerintahan suatu negara dan efektifitas kebijakan pembangunannya.

\section{KESIMPULAN DAN REKOMENDASI KEBIJAKAN}

\section{Kesimpulan}

Perempuan nelayan memiliki posisi yang strategis dalam program pengentasan kemiskinan yang sering disandang masyarakat nelayan. Posisi tersebut melekat pada perempuan nelayan yang berperan serta meningkatkan ekonomi keluarga melalui kegiatan produktif. Kegiatan produktif yang dijalankan dapat menunjang perekonomian keluarga yang pada akhirnya dapat menguatkan perekonomian desa pesisir. Seiring dengan itu maka status kemiskinan akan terkikis dengan kehidupan nelayan yang sejahtera. Namun, selama ini akses perempuan dalam pengembangan usaha sering terganjal oleh ketimpangan gender yang diberlakukan pemerintah sendiri. Program bebantuan untuk pemberdayaan masyarakat pesisir lebih diperuntukkan untuk laki-laki nelayan.

\section{Rekomendasi Kebijakan}

Ketimpangan gender yang terjadi pada masyarakat di lokasin kasus akan merugikan anggota masyarakatnya karena akan menurunkan kualitas kehidupan nelayan. Pemberdayaan yang bertujuan untuk meningkatkan kualitas manusia di wilayah pesisir seharusnya bersifat sensitif gender atau seimbang antara perempuan maupun laki-laki. Ketimpangan gender terutama pada akses produktif membuat perempuan nelayan sukar meningkatkan kemampuan mereka untuk berkontribusi dan mengembangkan potensinya secara maksimal. 
Ketimpangan gender sebenarnya mengganggu upaya dan akan merapuhkan pembangunan desa pesisir. Untuk itu, dibutuhkan upaya pemberdayaan bagi perempuan nelayan di lokasi kasus, terutama yang diarahkan pada tujuan peningkatan kompetensi dan akses produktif perempuan nelayan, sehingga perempuan nelayan akan memiliki kemampuan untuk berkontribusi dan mengembangkan potensinya secara maksimal dalam pembangunan ekonomi.

\section{DAFTAR PUSTAKA}

Anonymous. 2005. Pembangunan Berprespektif Gender. Laporan Penelitian Kebijakan Bank Dunia. Penerbit Dian rakyat. Jakarta.

Azahari, D.H. 2008. Indonesian Rural Women: The Role in Agricultural Development. Analisis Kebijakan Pertanian. 6(1).
Biro Pusat Statistik, 2012. Kabupaten Pandeglang Dalam Angka 2011. Kabupaten Pandeglang. Propinsi Banten.

Fauzi, A. 2005. Kebijakan Perikanan dan Kelautan Isu, Sintesis, dan Gagasan. Gramedia. Jakarta.

Kusnadi. 2002. Nelayan: Strategi Adaptasi dan Jaringan Sosial. Humaniora Utama Press. Bandung.

Kusnadi. 2002. Konflik Sosial Nelayan, Kemiskinan dan Perebutan Sumberdaya Perikanan.Penerbit LkiS. Yogyakarta.

Murniati, A. Nunuk P. 2004. Getar Gender; Buku Pertama. Yayasan Indonesia Tera. Magelang.

Salim, Agus. 2006. Teori dan Paradigma Penelitian Sosial. Buku Sumber Untuk Penelitian Kualitatif. Edisi Kedua. Tiara Wacana. Yogyakarta. 